REGARDS

SUR LECONOMIE ALLEMANDE

BULLETIN ECONOMIQUE DU CIRAC
Regards sur l'économie allemande

Bulletin économique du CIRAC

$89 \mid 2008$

Varia

\title{
Société et valeurs
}

MIEGEL Meinhard, PETERSEN Thomas, Der programmierte Stillstand.

Das widersprüchliche Verhältnis der Deutschen zu Wirtschaftswachstum und materieller Wohlstandsmehrung

\section{(2) OpenEdition}

Édition électronique

URL : http://journals.openedition.org/rea/3163

DOI : 10.4000/rea.3163

ISBN : 978-2-8218-0874-4

ISSN : 1965-0787

Éditeur

CIRAC

Édition imprimée

Date de publication : 1 décembre 2008

ISSN : 1156-8992

Référence électronique

"Société et valeurs », Regards sur l'économie allemande [En ligne], 89 | décembre 2008, mis en ligne le

13 janvier 2009, consulté le 22 septembre 2020. URL : http://journals.openedition.org/rea/3163 ; DOI : https://doi.org/10.4000/rea.3163

Ce document a été généré automatiquement le 22 septembre 2020.

(c) CIRAC 


\section{Société et valeurs}

MIEGEL Meinhard, PETERSEN Thomas, Der programmierte Stillstand. Das widersprüchliche Verhältnis der Deutschen zu Wirtschaftswachstum und materieller Wohlstandsmehrung

\section{RÉFÉRENCE}

MIEGEL Meinhard, PETERSEN Thomas, Der programmierte Stillstand. Das widersprüchliche Verhältnis der Deutschen zu Wirtschaftswachstum und materieller Wohlstandsmehrung, Olzog Verlag, Munich, 2008, 128 p.

1 «La capacité d'une société au progrès exige bien plus que le simple accroissement des biens matériels » L'Institut für Demoskopie d'Allensbach (voir REA 80/07) avait réalisé en avril/mai 2007 pour le compte du think tank IWG Bonn une enquête représentative pour saisir l'état d'esprit des Allemands à l'aube du XXI ${ }^{e}$ siècle. Si elle confirme une certaine propension à l'immobilisme, liée au vieillissement comme à une profonde mutation d'une société qui a littéralement conquis sa prospérité, elle révèle aussi que les Allemands aspirent aujourd'hui à des valeurs comme la sécurité ou la confiance. Pour le politique, cela signifie qu'au lieu de se focaliser sur la seule croissance, il doit aussi et même avant tout viser l'immatériel - en un mot : donner du sens à son action. L'étude laisse entrevoir comment pourrait réagir la société allemande aux bouleversement en cours. (ib) 